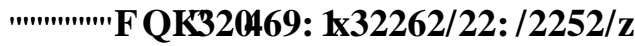

\title{
INTEGRATED SYSTEM OF TRANSPORT SAFETY
}

\section{ZINTEGROWANY SYSTEM BEZPIECZEŃSTWA TRANSPORTU}

\author{
Ryszard Krystek ${ }^{1}$, Marek Sitarz ${ }^{2}$, Józef Żurek ${ }^{3}$, Stanisław Gucma ${ }^{4}$
}

(1) Gdańsk University of Technology, Faculty of Civil and Environmental Engineering Politechnika Gdańska, Wydział Inżynierii Lądowej i Środowiska 80-952 Gdańsk, ul. Narutowicza 11

(2) Silesian University of Technology, Faculty of Transport

Politechnika Śląska, Wydzial Transportu 40 - 019 Katowice, ul. Krasińskiego 8,

(3) Air Force Institute of Technology Instytut Techniczny Wojsk Lotniczych 01-494 Warszawa, ul. Księcia Bolesława 6,

(4) Maritime University of Szczecin, Faculty of Navigation, Akademia Morska w Szczecinie, Wydzial Nawigacji 70-500 Szczecin, Waly Chrobrego 1/2

e-mails: (1) rkrystek@pg.gda.pl; (2)msitarz@psl.edu.pl; (3)jozef.zurek@itwl.pl; (4) gucma@am.szczecin.pI

\begin{abstract}
In January 2007 following a competitive bidding process the Minister of Science and Higher Education decided to award the PBZ 2/2006 contract to deliver a three year research project Integrated System of Transport Safety to a consortium of the Gdańsk University of Technology, Silesian University of Technology, Air Force Institute of Technology in Warsaw and Maritime University of Szczecin. The subject of this paper is to present the problem, project outline and its objectives.
\end{abstract}

Key words: road transport, rail transport, air transport, water transport, safety, accidents, fatalities, safety systems, reliability, integration

Streszczenie: W styczniu 2007 Minister Nauki i Szkolnictwa Wyższego, na podstawie konkursu na projekt badawczy zamawiany PBZ 2/2006, podjął decyzję o przyznaniu prawa realizacji trzyletniego projektu pt. "Zintegrowany system bezpieczeństwa transportu” konsorcjum naukowemu w składzie: Politechnika Gdańska, Politechnika Śląska, Instytut Techniczny Wojsk Lotniczych w Warszawie oraz Akademia Morska w Szczecinie. Przedmiotem niniejszego referatu jest opis problemu, założenia do projektu oraz jego cele.

Słowa kluczowe: transport drogowy, transport kolejowy, transport powietrzny, transport wodny, bezpieczeństwo, wypadki, ofiary śmiertelne, systemy bezpieczeństwa, niezawodność, integracja. 


\section{INTEGRATED SYSTEM OF TRANSPORT SAFETY}

\section{Introduction}

Because road crashes occur on a daily basis, we seem to have grown so accustomed to the problem, we hardly notice it anymore. It is only air, rail or sea disasters usually involving many deaths that make us stop and think. Because these crashes get extensive media coverage, politicians take interest and make promises to investigate the causes and make safety a top priority so that the same disaster is unlikely to happen again. But what is the actual strategy of lessons learned and what do we do to use our experience to create a better future?

Looking back on the history of transport systems we will come across a number of disasters known to have been caused by human error with enormous consequences. Today we see them as milestones on the road to better safety of transport. But they also demonstrate that we do not always learn from our mistakes and use tried-andtested solutions. What we certainly do not do well enough is improve the law or respect the safety conditions as evidenced in the recent air crash in Poland.

We are still looking for the right answers to some basic questions about the type of structure which could effectively prevent transport accidents (Sweedler 2007):

- How can we improve safety through a better understanding of the features that are common to accidents in different transport modes?

- How can integration of knowledge and experience from different modes of transport help with improving the effectiveness of prevention in the entire transport system?

- How can the collecting of knowledge on transport disasters, crashes and incidents gathered from research and analysis of the causes and circumstances be helpful with creating a better transport policy?

- How can international cooperation provide the key to solving the problem of transport risks?

\section{Transport losses}

According to the World Bank the total number of transport deaths is now more than 1.2 million people annually and continues to grow. The World Health Organisation estimates that transport accidents are the ninth biggest cause of death for external reasons and the forecasts for 2020 suggest that it will become the third (WHO, 2005). In EU countries transport accidents especially road accidents are the 
primary cause of deaths for external reasons among people up to 45 years of age, generating a total loss of more than 200 billion Euro annually, which exceeds the annual budget of the European Commission. Poland loses about 30 billion PLN annually which is more than $2 \%$ of GDP and the number transport fatalities is as high as 5,200 annually, ten times that of injuries with about $20 \%$ of them disabled for the rest of their lives (GAMBIT, 2005).

Transport accidents also inflict enormous loss to public morale as a result of the destructive impact they have on the quality of life of the victims and their families. Until now economic loss was considered the main factor that accelerated the efforts to build a Europe wide system of transport safety. But since 2001 with the intensifying threat of terrorist attacks, the pace of work on transport safety has been significantly accelerated, especially because the risk to transport infrastructure is the highest. This is why the most developed countries are now seeing transport safety as one of the criteria of quality of life and transport safety has now become a special priority. With transport safety included in the Framework Research Programme as strategic research area 9, Poland has clearly joined the process.

\section{The problems of dissimilarities and mutual links}

Transport safety is that feature of the system which allows us to use it without accidents or undesirable events. Transport safety is a new field of study and its basic terms, norms and measures have not been firmly established yet. Other open problems include studying the threats to safety and assessing safety (Żurek, 2003).

A review of safety systems enforcement and safety levels by transport branches showed a variety of systems and accident causes. The reason for this differentiation of how safety is organised, enforced and managed is that they each operate in a different space and use different facilities depending on the type of transport. Despite the differences what does not change is the safety philosophy, the causes of risks and the target that all decision-makers and transport users want to achieve. Studies of the safety of transport systems generally look at the following factors:

- risks to safety within the transport system and its environment;

- the transport systems' and external rescue systems' ability to prevent the threats and their effects;

- mutual relations between threats to safety and the effectiveness of prevention and mitigating the effects.

When analysed for their safety, transport systems can be divided into these subsystems: technical facilities (means of transport), crews or operators, support subsystems and system management centres. Each of the sub-systems generates risk which may be caused by an external disturbance (e.g. weather or environment) and internal disturbances produced by organisational and functional features, the 
"human factor" and ageing technologies, wear and tear of materials and other system deficiencies.

The errors of a transport system generating risks can be analysed using a simplified man - technical facility - environment model. When analysing the effects of human activity on safety, we should take account of the operator delivering his mission without disturbance and when faced with a threat to safety. The modern operator of a land vehicle, ship or aircraft is an educated specialist who oversees systems in an automated cabin and selects the incoming information, looks for answers to questions as they arise and takes decisions to solve problems in a sequence as they appear. The operator provides the backup for automated controls operated in an open system. Even with modern technologies and automated controls, the operator is taken by surprise when unexpected circumstances appear and his mistakes are important causes of accidents and disasters.

Observations of real transport systems show that man as operator is the system's weakest link as can be seen from accident statistics. When operators make mistakes and cause risks, the reasons for the mistakes can be traced back to:

- lack of professional knowledge (low level of education or failure to understand the task);

- forgetting the task because a procedure or activity have not been repeated or practiced (routine, lack of practice);

- insubordination because of their personality, lack of control or motivation;

- no predisposition for the job (health, personality traits).

The mistakes of a transport operator can be analysed if we have access to training documentation, aptitude tests and personality tests. If these data are available from a computer database, they can be processed to formulate some general conclusions and improve the training process and practice. If applied to an error model, which processes classified sequences of events placed on axes of working time, length of simulator practice, length of professional life, etc., the data can be used to determine the likelihood of these risks and how the risks will change. To ensure that we draw the correct conclusions about the influence of man on transport safety, we need other probabilistic characteristics of the random processes when mistakes are made (Smalko, 2007).

When designing a means of transport, to be considered are the aspects of utility and safety set out in regulations and standards, in design theory and methods and the latest technologies of production. Consequently, a means of transport generates risks because:

- the structure is deficient; 
- the programme for operating the machine does not take account of the nature of the operation or wear and tear;

- operating standards are not observed;

- operating procedures and technologies are wrong;

- functional elements and systems suffer accidental damage.

The system of driving causes a threat when:

- $\quad$ the mission is poorly prepared and communicated;

- $\quad$ wrong or incomprehensible information and decisions are given;

- $\quad$ the weather or environment are wrongly identified;

- communications is disturbed, etc.

\section{Independence of transport research}

The public have a right to objective opinions about the causes or circumstances of a disaster, accident or incident within the transport system when people have lost their lives, have been injured or exposed to a risk. This is why the public should be given a legal guarantee that there will be an independent transport safety examination to be carried out irrespective of the circumstances of the disaster, accident or incident. The world's first organisation to have given such guarantees to the public was established in the USA in 1967. The then president Johnson asked professor Haddon to establish an independent institution to integrate road, rail, air, water and pipeline transport safety research. That gave way to the establishment of the National Transportation Safety Board (NTSB), a body appointed by and answerable to the Senate and President.

Almost half a century into the USA's transport safety system history, Americans are certain that to achieve any improvements there must be an independent organisation whose objective is to study the causes and circumstances of incidents, accidents and disasters in all five transport branches. They will also say that by bringing together in one organisation many specialists from different fields, and particularly those whose expertise applies to several modes of transport, such as psychology, medicine, meteorology, theory of systems, encourages the development and progress in transport safety. A combination of independent research and multi-disciplinary approach to safety is the key to the NTSB's success and its future development.

In Europe the Netherlands is the only country to have achieved this goal: in 2005 the Parliament established the Dutch Safety Board (DSB). Its fundamental assumption is that "the right to independent research is the only way to establish what really happened and why". Independence is also a way to promote democracy because objective opinion lies at its foundations (van Vollenhoven, 2001).

Other countries are also beginning to introduce concepts of an integrated system of transport safety research. Australia, Canada, Sweden, Norway, Finland and New 
Zealand have already built their structures, although with some differences in terms of the powers and scope of operation. Air traffic agencies have the longest history of being separate organisations. They have a huge advantage over other modes of transport in the form of the strong worldwide organisation of ICAO, which is understandable given the frequency and density of modern aviation and the need to operate modern standards that are applicable all over the world.

The NTSB has gathered a lot of experience over the forty years of integrated efforts to improve transport safety. In his 20 years of work for the NTSB Sweedler also helped build the organisation. Today it is divided into four departments:

- finance and operations,

- exchange of knowledge between teams from different branches of transport,

- development of new research techniques,

- key issues in transport safety.

\section{Outline of ZEUS project}

The initial objective of the project is to integrate efforts for building a transport safety system which will operate as a consistent, statutory and research-based policy rather than a set of ad hoc measures when a disaster happens. Today worldwide many countries have built and are operating similar systems. Poland's objective should be to join the mainstream policies and help build a Europe-wide transport safety system. The important first step in opening project work will be to develop methods for identifying the differences and mutual links between safety systems in road, rail, air and water transport (including urban and regional transport) in Poland and Europe. The basic criterion that should be followed in planning transport systems is the "safety first" principle with emphasis on interdisciplinary data and knowledge bases (Krystek, R. 2008).

The main goal of ZEUS is to develop a model of an integrated transport safety system for decision-makers as a tool for making informed decisions about the development of transport means and infrastructure and for specialists that will implement the decisions. Modern transport is a complex activity requiring politicians, decision-makers and specialists to integrate goals, strategies and measures to ensure a safe transport. If it is to be delivered successfully, the transport safety policy must have a well defined vision, main goal, intermediate objectives and indicators for measuring effectiveness. If it is to be integrated, Poland's transport safety policy will bring together the fragmented parts of the structure from different branches of transport. They involve the different functional arrangements, information, organisation, legal, technical, spatial and human resources elements. To do that will require models and simulations of the operations of an integrated system of transport safety taking account of human factors, environmental protection and technical and technological factors (Gucma, S. 2008; Mieloszyk, E. 2008). 
Designed to build the European Road Safety Observatory (www.erso.eu), the SafetyNET project first analysed different ways to define independent research in the area of transport safety. In building an independent structure we are always faced with the problem of how to establish an organisation which will be funded by the government but at the same have the right to critique it. But this is how it actually works in countries with highly developed democratic structures and well functioning transport safety systems! While the USA's National Transportation Safety Board or the Netherlands's Dutch Safety Board are funded by government administration, they have the right to be critical about the government and its agencies.

\section{Conclusions}

Because major disasters do not happen often, public pressure is not constant and demands to establish an independent body to ensure transport safety and carry out an investigation when an accident happens will eventually subside. Public and political pressures only appear shortly after a disaster. In 1994 the UE issued Directive 94/56 which said that investigating the causes and circumstances of transport disasters, accidents and incidents can be done by an independent agency. What this means is that it took 30 years to shape the political will to establish such a body, that is since the establishment of the NTSB in the US. In addition it is important to say that it was not until ten years later in February 2005 that the Dutch Parliament passed the act to set up Europe's first independent organisation, the Dutch Safety Board.

Developed by a Consortium of representatives of road, rail, air and water transport, the assumptions of the Polish Integrated System of Transport Safety project are as follows:

- we have to have a uniform system of national transport safety councils in all European Union countries to gradually integrate the individual national commissions from different transport branches into a single structure;

- in Poland the first step could be to integrate the State Aviation Accident Commission with the State Rail Accident Commission;

- the model for introducing changes in the countries should be the Dutch model; the Dutch Safety Board - the official Partner in delivering ZEUS.

When comparing the different levels of risk in the transport branches, we are usually quite surprised to see such high disproportions; as much as $95 \%$ of the casualties are road accidents victims. Compared with that the other three branches of transport combined have small losses. Perhaps this is now the right moment to remember this well-known quote "We all know that flying is dangerous. But maybe this is why it is so safe". Another important quote is from dr. Lauber, a former NTSB director "Lack of accidents does not necessarily mean the existence of safety". 


\section{References}

[1] GAMBIT (2005): Krajowy Program Bezpieczeństwa Ruchu Drogowego Wizja zero. Politechnika Gdańska, Katedra Inżynierii Drogowej. Ministerstwo Infrastruktury. Warszawa 2005.

[2] Gucma, S. red. (2008): Metody symulacyjne $w$ inżynierii ruchu morskiego. Wydawnictwa Akademii Morskiej, Szczecin, 2008.

[3] Krystek, R., Michalski L., Żukowska J. (2008): Integrated System of Transport Safety. 9th World Conference on Injury Prevention and Safety Promotion. Merida, Mexico. 15-18 March, 2008.

[4] Mieloszyk, E. (2008): Nieklasyczny rachunek operatorów w zastosowaniu do uogólnionych układów dynamicznych. Wydawnictwa IMP PAN, Gdańsk, 2008.

[5] Nowak A., Sitarz M., Verbicki W.: Analysis of Brake - Wheelset Railway Dynamics Turing the Motion, Mechanika 2004, Nr 2 (46), str. 52 - 59 Grant KBN Nr 4T12C 03524 „Projekt szybkich połaczeń kolejowych w Polsce w ramach europejskiego systemu transportowego".

[6] Smalko, Z. (2007): Charakterystyki spolegliwości układu człowiek-maszynaotoczenie. Materiały Szkoły Niezawodności PAN, Wydawnictwo ITE ,Radom 2007.

[7] Sweedler, B. (2007): Improving Transportation Safety - the Integrated Multimodal Approach. First International Seminar ZEUS, Pultusk, 20-22 June, 2007.

[8] Van Vollenhoven, P. (2001): Independent accident investigation: every citizen's right, society's duty. $3^{\text {rd }}$ European Transport Safety Lecture. European Transport Safety Council. Brussels, January 2001.

[9] WHO (2005): World Report on Road Traffic Injury Prevention. Geneve, 2005.

[10] Żurek J. (2003): The method of evaluation of transport system availability". Safety and Reliability International Conference To Safer Life and Environment, KONBiN'03. Materiały Konferencyjne, Wydawnictwo ITWL, Warszawa 2003, Nr 3/2003 


\section{ZINTEGROWANY SYSTEM BEZPIECZEŃSTWA TRANSPORTU}

\section{Wstęp}

Wypadki w transporcie drogowym stały się wydarzeniami wręcz codziennymi, do których przyzwyczailiśmy się na tyle, że już ich prawie nie zauważamy. Jedynie katastrofy w transporcie lotniczym, kolejowym lub morskim, które zazwyczaj powodują duże straty lub pociaggają za sobą większą liczbę ofiar, zatrzymują naszą uwagę na dłużej. Ponadto fakt, że są to wydarzenia medialne, skupiają uwagę polityków, którzy wówczas deklaruja gotowość wyjaśnienia przyczyn katastrofy, a w ogóle zajęcie się problemem bezpieczeństwa w tak intensywny sposób, że powtórzenie się takich samych okoliczności katastrofy wydaje się wręcz niemożliwe. Jak więc naprawdę wygląda obecnie strategia „lessons to learn”, by na podstawie doświadczeń wyciagganych z przeszłości tworzyć lepszą przyszłość.

Sięgając do historii rozwoju systemu transportu możemy wskazać wiele katastrof, które do dziś są cytowane jako przykłady niewielkich często błędów człowieka, mających jednak wręcz niewyobrażalnie wielkie skutki. Obecnie są one traktowane jako kamienie milowe postępu w poprawie bezpieczeństwa transportu. Jednakże są one także dowodem, że nie zawsze uczymy się na błędach, i nie zawsze stosujemy najlepsze, sprawdzone praktyki. A z całą pewnością niezbyt intensywnie doskonalimy prawo i niezbyt sumiennie respektujemy obowiązujące nas warunki bezpieczeństwa. Ostatnia katastrofa lotnicza w Polsce jest tego konkretnym dowodem.

Nadal poszukujemy właściwej odpowiedzi na podstawowe pytania, dotyczące budowy struktury, skutecznie przeciwdziałającej powstawaniu wypadków w transporcie Sweedler (2007):

- Jak można poprawić bezpieczeństwo poprzez właściwe rozumienie cech wspólnych wypadków w różnych gałęziach transportu?

- Na ile integracja wiedzy i doświadczeń, zdobytych w różnych gałęziach transportu, może korzystnie wpłynąć na efektywność działań prewencyjnych w całym systemie transportu?

- Jak gromadzenie wiedzy o katastrofach transportowych, wypadkach $i$ incydentach, zdobywanej w badaniach naukowych i analizach przyczyn i okoliczności zdarzeń, może być pomocne w tworzeniu lepszej polityki transportowej? 
- Na ile międzynarodowa współpraca może stanowić klucz do rozwiązania problemu ryzyka w transporcie?

\section{Straty $w$ transporcie}

Według danych Banku Światowego łączna liczba śmiertelnych ofiar w transporcie przekroczyła już 1,2 mln osób rocznie i ciagle rośnie. Światowa Organizacja Zdrowia WHO szacuje, że wypadki w transporcie są obecnie na 9 miejscu na liście przyczyn zgonów z powodów zewnętrznych, a prognozy na rok 2020 przewidują miejsce trzecie (WHO, 2005). W krajach UE wypadki w transporcie, głównie drogowym, są obecnie pierwszą przyczyną zgonu z powodów zewnętrznych ludzi w wieku do 45 lat, a łączne straty szacuje się na ponad 200 mld Euro rocznie, co przekracza roczny budżet Komisji Europejskiej. Polska natomiast traci rocznie około $30 \mathrm{mld} \mathrm{zl}$, co stanowi ponad 2\% PKB, a liczba śmiertelnych ofiar w transporcie sięga 5,2 tys. rocznie, liczba rannych dziesięciokroć tyle, a około $20 \% \mathrm{z}$ nich pozostaje inwalidami na całe życie (GAMBIT, 2005).

Wypadki w transporcie powodują również ogromne straty moralne społeczeństwa, które są wynikiem destrukcyjnego ich oddziaływania na jakość życia ofiar i ich rodzin. Dotychczas jedynie straty ekonomiczne były uznawane za główny czynnik przyspieszający prace nad europejskim systemem bezpieczeństwa transportu. Tymczasem od 2001 roku nasilające się ataki terrorystyczne znacząco wzmogły tempo prac nad bezpieczeństwem transportu, którego infrastruktura stała się najbardziej podatna na zagrożenia. Dlatego w krajach o najwyższym poziomie rozwoju bezpieczeństwo transportu jest już postrzegane jako jedno $\mathrm{z}$ najważniejszych kryteriów oceny jakości życia, co oznacza nadanie specjalnego priorytetu działaniom na rzecz poprawy bezpieczeństwa transportu. Wpisanie zatem bezpieczeństwa transportu w Ramowy Program Badań Naukowych, jako strategiczny obszar badawczy nr 9 oznacza, że Polska także włącza się w ten proces.

\section{Problemy odrębności i wzajemnych powiązań}

Bezpieczeństwo w transporcie rozumiemy jako właściwość systemu, umożliwiającego działanie w danych warunkach środowiskowych, bez wypadków i niepożądanych zdarzeń. Tworząca się nowa dyscyplina naukowa, jaką jest bezpieczeństwo transportu, ma stosunkowo słabo ugruntowane podstawowe pojęcia, normy i miary. Otwartymi problemami pozostają też badania zagrożeń bezpieczeństwa i ocena jego stanu (Żurek, 2003).

Identyfikacja systemów nadzoru bezpieczeństwa oraz stanu bezpieczeństwa w poszczególnych gałęziach transportu wykazała różnorodność w organizacji systemów i okoliczności wypadków. Odrębność organizacji, nadzoru i metod 
zarządzania bezpieczeństwem wynika $\mathrm{z}$ różnych przestrzeni ruchu i różnych obiektów technicznych wykorzystywanych w poszczególnych rodzajach transportu. Mimo różnic niezmienna jest filozofia bezpieczeństwa, przyczyny zagrożeń i cel, do którego zmierzają decydenci oraz uczestnicy ruchu wszystkich rodzajów transportu. Badania stanu bezpieczeństwa systemów transportu najogólniej można sprowadzić do analizy czynników takich jak:

- ryzyko zagrożeń bezpieczeństwa powstałe w systemie transportu i jego otoczeniu;

- możliwość przeciwdziałania występującym zagrożeniom i ich skutkom przez system transportu oraz przez zewnętrzne systemy ratownicze;

- wzajemne relacje występujące między zagrożeniem bezpieczeństwa a skutecznością przeciwdziałania i skutecznością łagodzenia skutków zaistniałych zdarzeń.

System transportu będący przedmiotem analizy z punktu widzenia bezpieczeństwa zawiera takie podsystemy jak: obiekty techniczne (środki transportu), załogi lub operatorów, podsystem zabezpieczenia działań i ośrodek kierowania systemem. Każdy $\mathrm{z}$ wymienionych podsystemów jest generatorem zagrożeń, których przyczyną mogą być: zakłócenia zewnętrzne (np. klimatyczno-przyrodnicze) i zakłócenia wewnętrzne pochodzące od właściwości organizacyjnych, funkcjonalnych, „czynnika ludzkiego” oraz starzenia się techniki, zużycia materiałów, a także innych niedoskonałości systemu.

Dla potrzeb analizy błędów w działaniu systemu transportowego generującego zagrożenia można na wstępie rozpatrywać uproszczony model jaki tworzy układ: człowiek - obiekt techniczny - otoczenie. Analizując wpływ człowieka na bezpieczeństwo układu należy uwzględniać model działania operatora $\mathrm{w}$ realizacji niezakłóconej zaplanowanej misji oraz działania w sytuacjach zagrożenia bezpieczeństwa. Współczesny operator pojazdu lądowego, statku morskiego albo powietrznego, to najczęściej wykształcony specjalista, który w zautomatyzowanej kabinie nadzoruje systemy i prowadzi selekcje napływających informacji, poszukuje odpowiedzi na pojawiające się pytania oraz podejmuje decyzje rozwiązując sekwencyjnie pojawiające się problemy. Stanowi rezerwę dla automatyki realizujących sterowanie w układzie otwartym. Mimo zastosowania nowoczesnej techniki i automatyki, rzeczywistość zaskakuje operatora nieprzewidzianymi okolicznościami, a jego błędy w działaniu stanowią istotne przyczyny wypadków i katastrof.

Obserwacja rzeczywistych systemów transportowych wskazuje, że człowiek - jako operator - stanowi najsłabsze ogniwo w rozpatrywanym systemie, o czym świadczą statystyki wypadków. Człowiek obsługujący urządzenia może również popełniać błędy powodujące zagrożenia, które pochodzą od: 
- niewiedzy w danej profesji (niski poziom wyszkolenia lub niezrozumienie zadania);

- niepamięci wynikającej z braku powtórzeń procedur lub czynności (rutyna, brak treningu);

- niesubordynacji spowodowanej charakterem, brakiem kontroli lub motywacji;

- braku predyspozycji do danego zawodu (stan zdrowia, cechy osobowości).

Racjonalna analiza błędów operatora środka transportu staje się możliwa jeżeli dysponujemy dokumentacją procesu szkolenia i badania predyspozycji oraz cech osobowości. Jeżeli wymienione dane znajdują się w bazie informatycznej i można je przetwarzać oraz formułować uogólnione wnioski doskonalące proces szkolenia oraz treningu. Model analizy błędów oparty na przetwarzaniu odpowiednio poklasyfikowanych ciagów zdarzeń rozmieszczonych na osiach czasu pracy, czasu treningu na symulatorach, czasu życia zawodowego itp. może wyznaczać ryzyko wystapienia tych błędów oraz tendencję zmian tego ryzyka. Do poprawnego wnioskowania o wpływie człowieka na bezpieczeństwo w transporcie niezbędne są również inne charakterystyki probabilistyczne losowych procesów popełniania błędów (Smalko, 2007).

W procesie konstruowania środka transportu, obok walorów użytkowych uwzględnia się aspekt bezpieczeństwa wyrażony w obowiązujących przepisach i normach, w obecnie istniejącej teorii oraz w metodach projektowania, a także wykorzystuje się najnowsze zdobycze technologii wytwarzania. Środek transportu powoduje więc zagrożenie przez niewłaściwe funkcjonowanie wywołane:

- niedoskonałością konstrukcji;

- niedopasowaniem programu eksploatacji do natury zużycia i starzenia;

- nieprzestrzeganiem ustalonych norm eksploatacyjnych;

- błędnymi procedurami i technologiami obsługi;

- losowymi uszkodzeniami elementów i układów funkcjonalnych.

System kierowania natomiast powoduje zagrożenie poprzez:

- $\quad$ nieodpowiednie przygotowanie i przekazanie misji;

- $\quad$ błędne lub niezrozumiałe przekazywanie informacji oraz decyzji.

- błędne rozpoznanie pogody lub środowiska;

- $\quad$ zakłócenia w łączności itp;

\section{Niezależność badań bezpieczeństwa transportu}

Społeczeństwo ma prawo do obiektywnych opinii o przyczynach i okolicznościach katastrofy, wypadku czy incydentu w systemie transportu w sytuacji, gdy poniosło 
straty w postaci życia obywateli, doznało uszczerbku na ich zdrowiu, bądź zostało zagrożone wystawieniem zdrowia i życia obywateli na ryzyko ich utraty. Społeczeństwo zatem powinno mieć prawne gwarancje, że niezależne badania w zakresie bezpieczeństwa transportu mogą być przeprowadzone i będą wykonane niezależnie od okoliczności w jakich katastrofa, wypadek, czy incydent wydarzyły się. Pierwsza w świecie organizacja, dająca społeczeństwu takie gwarancje, powstała w USA w 1967 roku. Wówczas prezydent Johnson powierzył profesorowi Haddonowi misję utworzenia niezależnej instytucji, integrującej badania nad bezpieczeństwem transportu drogowego, kolejowego, lotniczego, wodnego i rurociagowego. Tak powstała Państwowa Rada Bezpieczeństwa Transportu NTSB (National Transportation Safety Board), powoływana i zależna jedynie od Senatu i Prezydenta.

Po prawie pół wieku funkcjonowania systemu bezpieczeństwa transportu w USA Amerykanie są przekonani, że warunkiem koniecznym poprawy jest utworzenie niezależnej organizacji, której celem jest badanie przyczyn i okoliczności incydentów, wypadków i katastrof we wszystkich pięciu gałęziach transportu. Twierdzą ponadto, że skupienie w jednej organizacji wielu specjalistów z różnych dyscyplin, a zwłaszcza $\mathrm{z}$ tych, które mają zastosowanie $\mathrm{w}$ kilku gałęziach transportu, na przykład; psychologia, medycyna, meteorologia, teoria systemów, umożliwia prowadzenie prac fundamentalnych dla postępu w działaniach na rzecz poprawy bezpieczeństwa transportu. Zatem kombinacja niezależności badań i wielodyscyplinarności podejścia do problemu bezpieczeństwa stanowi o sukcesach NTSB i bardzo korzystnych prognozach dalszego rozwoju.

W Europie jedynie w Holandii zdołano w całości osiagnąć cel: w 2005 Parlament utworzył Krajową Radę Bezpieczeństwa DSB (Dutch Safety Bard). Jej fundamentalnym założeniem jest, że "prawo do niezależnych badań jest jedyną drogą do ustalenia, co naprawdę się zdarzyło i dlaczego tak się stało". Ta niezależność jest również formą pomocy w rozwoju demokracji, jako że obiektywność sądów jest jej podstawą (van Vollenhoven, 2001).

Inne kraje także zaczynają wdrażać koncepcje zintegrowanego systemu badań bezpieczeństwa transportu. Australia, Kanada, Szwecja, Norwegia, Finlandia oraz Nowa Zelandia zbudowały już struktury, jednakże różniące się nieco w swoich koncepcjach i zasięgu działania. Najdłużej $\mathrm{w}$ separacji pozostają agencje bezpieczeństwa ruchu lotniczego, których ogromną przewagą nad innymi rodzajami transportu jest silna organizacja światowa ICAO. Jest to poniekąd zrozumiałe, jako że współczesne lotnictwo, przy swej częstotliwości lotów i gęstości ruchu, musi operować standardami o światowym zasięgu.

NTSB nabyła wiele doświadczenia w okresie czterdziestu lat zintegrowanych działań na rzecz poprawy bezpieczeństwa transportu. Sweedler (2007) podzielił się 
doświadczenia zdobytymi podczas 20 lat swojej pracy w NTSB, gdy rozwijał strukturę tej instytucji, która obecnie jest podzielona na cztery wydziały:

- finanse i działania operacyjne organizacji,

- wymiana wiedzy między zespołami operującymi w poszczególnych gałęziach transportu,

- rozwój nowych technik badawczych,

- kluczowe zagadnienia w bezpieczeństwie transportu.

\section{Założenia Projektu ZEUS}

Wstępnym celem projektu jest integracja działań na rzecz budowy systemu bezpieczeństwa $\mathrm{w}$ transporcie tak, aby jego funkcjonowanie nie było efektem doraźnych reakcji społeczeństwa na pojedyncze katastrofy, lecz metodycznym działaniem, zapewnionym prawem ustanowionym na bazie solidnych i dobrze udokumentowanych badań naukowych. Obecnie w świecie jest niewiele krajów, które zbudowały i eksploatują takie systemy. Zadaniem Polski powinno więc być dołączenie do tej grupy i współuczestniczenie w budowie europejskiego systemu bezpieczeństwa transportu. Kluczowym zatem zadaniem, otwierającym prace nad projektem będzie zatem opracowanie metod określania odrębności i wzajemnych powiązań systemów bezpieczeństwa w transporcie drogowym, kolejowym, lotniczym i wodnym (uwzględniając również zagadnienia transportu miejskiego i regionalnego) w Polsce i Europie. Przyjęto więc podstawowe kryterium w procesie planowania systemów transportowych „safety first”, w którym interdyscyplinarne bazy danych i bazy wiedzy odgrywają bardzo znaczącą rolę (Krystek, 2008).

Głównym celem projektu ZEUS jest opracowanie modelu zintegrowanego systemu bezpieczeństwa transportu tak, by służył on decydentom jako narzędzie do podejmowania właściwych decyzji dotyczących budowy i rozwoju infrastruktury oraz środków transportu, a także specjalistom realizującym te decyzje. Współczesny bowiem transport jest złożoną działalnością, która wymaga od polityków, decydentów i specjalistów umiejętności integrowania celów, strategii i środków warunkujących możliwość znalezienia właściwego rozwiązania dla zapewnienia bezpieczeństwa transportu. Sukces planowania i wdrażania polityki bezpieczeństwa transportu zależy przede wszystkim od właściwego zdefiniowania wizji, celu głównego, celów pośrednich oraz wskaźników efektywności środków bezpieczeństwa. Integracja systemu bezpieczeństwa transportu w Polsce będzie więc obejmować, rozproszone dotychczas w poszczególnych gałęziach transportu, elementy struktury systemu; funkcjonalne, informacyjne, organizacyjne, prawne, techniczne, przestrzenne i kadrowe. Działania te wymagaja stworzenia modeli i przeprowadzenia badań symulacyjnych zintegrowanego systemu bezpieczeństwa, uwzględniającego czynniki ludzkie, ochronę środowiska oraz czynniki techniczne $\mathrm{i}$ technologiczne (Gucma, S. 2008; Mieloszyk, E. 2008). 
Już we wstępnych pracach nad projektem SafetyNET, którego głównym celem jest budowa „Europejskiego Obserwatorium Bezpieczeństwa Ruchu Drogowego" (www.erso.eu) analizowano różne pojęcia niezależności badań bezpieczeństwa transportu. Tworząc bowiem niezależną strukturę zawsze stajemy przed problemem, jak powołać organizację, która będzie finansowana przez administrację państwową, a jednocześnie będzie miała prawo ją krytykować. A jednak $w$ krajach o wysokim poziomie demokracji i bardzo dobrze funkcjonujących systemach bezpieczeństwa transportu, tak jest! W USA Państwowa Rada Bezpieczeństwa Transportu (NTSB), czy Rada Bezpieczeństwa w Holandii (DSB), mimo że są finansowane przez administrację rządową, mają prawo do wypowiadania krytycznych opinii o niej i agencjach jej podległych.

\section{Wnioski}

Wielkie katastrofy nie zdarzają się często, dlatego też trudno oczekiwać stałej presji społeczeństwa, by utworzyć niezależną instytucję zajmująca się kontrolą stanu systemu bezpieczeństwa $\mathrm{w}$ transporcie, a gdy katastrofa się wydarzy, obiektywnych badań jej przyczyn i okoliczności. Taka potrzeba zgłaszana przez społeczeństwo oraz presja, zwłaszcza ze strony polityków, pojawia się tylko bezpośrednio po katastrofie. W 1994 UE wydała dyrektywę 94/56, w której stwierdzono, że badania przyczyn i okoliczności katastrof, wypadków i incydentów $\mathrm{w}$ transporcie mogą być prowadzone przez niezależną agencję. Oznacza to, że proces kształtowania woli politycznej sformułowania prawa do utworzenia takiego organu trwał 30 lat, licząc od daty powstania NTSB w USA. Ponadto warto dodać, że dopiero w 10 lat później, w lutym 2005 parlament holenderski przyjął ustawę o utworzeniu pierwszej w Europie niezależnej organizacji Holenderskiej Rady Bezpieczeństwa DSB.

Prezentując zatem założenia do polskiego projektu „Zintegrowanego Systemu Bezpieczeństwa Transportu", opracowane w I fazie jego realizacji przez Konsorcjum składające się z przedstawicieli transportu drogowego, kolejowego, lotniczego i wodnego, stwierdzamy co następuje:

- Konieczne jest ujednolicenie systemu krajowych rad bezpieczeństwa transportu we wszystkich krajach członkowskich Unii Europejskiej, powinno to prowadzić do stopniowej integracji poszczególnych, krajowych komisji w poszczególnych gałęziach transportu, w jedną całość.

- W Polsce w pierwszym kroku można zintegrować Państwową Komisję ds. Wypadków Lotniczych z Państwową Komisją ds. Wypadków Kolejowych.

- Wzorcem do zmian $\mathrm{w}$ poszczególnych krajach powinien być model holenderski; Dutch Safety Board - oficjalny Partner w realizacji projektu ZEUS. 
Kiedy porównujemy różnice poziomów zagrożenia zdrowia i życia ludzi w poszczególnych gałęziach transportu, jesteśmy najczęściej zdziwieni tak wielką dysproporcją wskaźników; aż $95 \%$ ofiar bowiem pochodzi z wypadków na drogach. $W$ porównaniu do tego pozostałe trzy gałęzie dają łącznie niewielkie straty. Może właśnie w tym momencie warto przypomnieć znane powiedzenie; „Wszyscy wiemy, że latanie jest niebezpieczne. Ale to właśnie dlatego jest ono tak bezpieczne". Warto również wspomnieć maksymę dr Lauber, byłego dyrektora NTSB; „Brak wypadków niekoniecznie oznacza istnienie bezpieczeństwa”.

Professor RYSZARD KRYSTEK, Ph.D., D.Sc. full professor at Gdansk University of Technology. Specialisation: transport policy, airport and road design, highway engineering and road safety.

Dr. MAREK SITARZ, professor at Silesian University of Technology. Specialisation: budowa i eksploatacja maszyn, logistyka, marketing i zarządzanie $\mathrm{w}$ zakładach transportowych.

Dr. JÓZEF ŻUREK, professor at Air Force Institute of Technology in Warsaw. Specialisation: budowa i eksploatacja maszyn, transport, bezpieczeństwo i niezawodność systemów,

Professor STANISŁAW GUCMA, Ph.D., D.Sc., captain, full professor at the Maritime University of Szczecin. Specialisation: inżynieria ruchu morskiego. 